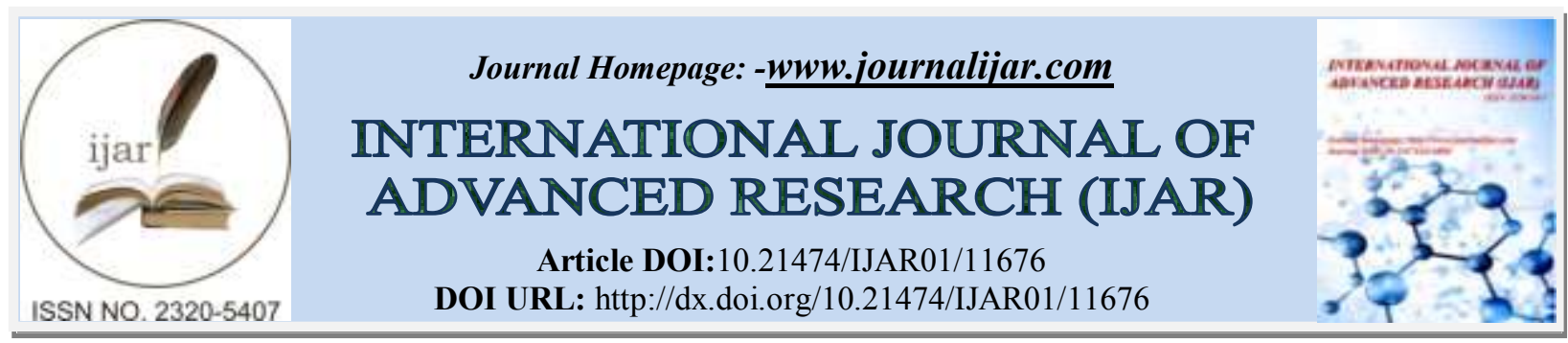

RESEARCH ARTICLE

\title{
GRAPHICS OF UZBEKISTAN IN THE INDEPENDENCE PERIOD
}

\author{
Obidjon Oripovich Abdullaev \\ Independent Researcher, Department of History And Theory Of Fine Arts, National Institute of Art and \\ Designnamed after Kamoliddin Behzod,Tashkent, Uzbekistan.
}

\section{Manuscript Info}

Manuscript History

Received: 10 July 2020

Final Accepted: 14 August 2020

Published: September 2020

Key words:-

Graphic Art, Book Illustration, Realism,

Watercolor, Postwar Art, Tendency,

Illustration, Easel Graphic Art
\end{abstract}

\section{Abstract}

The following article is dedicated to the research of formation and development of graphic art of Uzbekistan of Independence period. The author analyzes the works of artists and this sphere, which was facing difficulties in early 1990ies. The article also devoted to a modern graphic artists, their works and teaching experience for further development of this sphere.

Copy Right, IJAR, 2020,. All rights reserved.

\section{Introduction:-}

In the 21st century, the age of information and technology, the role of the fine arts has taken on a slightly modern look. Styles and themes based on various concepts have become popular in the fine arts.Due to the market economy, various areas have developed rapidly. As a result, works of art began to be created on demand.As a result, mixed technologies have also emerged. Methods specific to the traditional schools that have been formed to date have been synthesized.Such actions are reflected in the work of masters who try to make a living in everyday life, the preservation of old school traditions, protection from modern external influences, and their continuation pose pressing problems today.

Uzbek graphics has its own specific traditions. From the first half of the twentieth century, a school of graphics was formed in our country, and talented creators emerged. They have made a worthy contribution to the development of this art, creating effectively in almost all areas of graphics. In recent years, however, this field has begun to lag behind other areas of our national fine arts. This is due not only to creative but also to socio-economic reasons.

\section{The Main Findings And Results:-}

Until the end of the twentieth century, several artists working in the field of graphic art MedatKagarov, B.Jalolov, L.Ibragimov, and others changed their directions, paid great attention to visual art (painting), which led to the emergence of defects in the field of graphics. In the development of modern art, there has been an attempt to squeeze out graphic art. One of the main problems in the art of graphics was primarily related to the changes of the period. One of the reasons for this is that the process of ordering graphic artists by the state has stopped. In a market economy, their creative activity did not justify itself materially. No concept has been developed for the organization of an exhibition of individual graphic artists, all attention has been paid to painting. Organizing an exhibition requires a lot of effort and money. Modern computer design and the popularity of a variety of programs are replacing manual labor, including book graphics. Young people who have just learned to use computers, have no experience in this field, and are not engaged in graphic arts perform the task, which was done by professional artists of the last century, today. State and non-state publishing houses and manufacturing enterprises stopped cooperating 
with specialist artists. There are only a few numbers of graphic works that adorn the interior of literature of different genres and types, published by many publishers.

It is noted that by the end of the 1990s there was a significant creative growth in the graphic arts of Uzbekistan. The process of art exhibitions, as well as the interest of the audience in graphic works evidence this. This rapid development of the art is due not only to the frequent participation of graphic artists in exhibitions, but also to their completely different approach to graphics. Besides, the unique capabilities of graphics play an important role here. Rejecting the usual notions of graphics, an entirely new form and artistic style emerged, in which it was observed that they had completely deviated from the traditions of graphics and approached painting and monumental painting.

In these abstract compositions, a painting-specific approach prevails over graphic lines. The essence of graphic paintings on paper is deeply solved through the alternative compositional solution of the image, the symbolism of the characters and the expressive form. Along with these, abstract and semi-abstract works with symbolic characters were continued in a graphic style.

L.Tiora, a student of E.Iskhakov, who developed a system of symbols and signs for the last twenty years, also tried to combine Arabic and Chinese calligraphic writing in his work "Calligraphy-impulse" (tree trunk mixed with paper (text) scrolls (installation)). Although L. Zufari's works were created under the influence of E. Iskhakov's concept of systems and symbols, his works have a unique independent approach. His works combine stone and its surface with symbolic inscriptions. ("Turkish Corners", 1993). In the compositions of T.Ayupov there is a tendency to symbolism, in the works of Yu.Alagir the compositions of abstract symbols prevail. In the 90s, exhibitions and galleries featured works by graphic artists Murad and Muhammad Fozilov in a strong, symbolic and cosmogonic spirit, created with the help of a pen and a ruler. Graphic artists D.Mirsalimov, A.Ligay, and A.Lilar have achieved great success in watercolor technique.

It is the Academy of Arts of Uzbekistan, together with several art historians and representatives of the graphic industry, on the development of graphic art and the improvement of its material and technical base "Is graphics in line with the times?" A roundtable discussion was held on the topic and many problems in the field and their solutions were discussed at the meeting, which was dedicated to overcoming several problems in the field of graphics. At this event, it was also agreed that the solution to the problems will be implemented in stages, but it is still difficult to observe any progress.

In December 2019, a personal exhibition of the master of graphic arts A.Mamajonovwas organized in the Central Exhibition Hall of the Academy of Arts of Uzbekistan. The main purpose of the exhibition was to preserve the traditions of the school of graphics, to pass it on to future generations and to keep it on the edge of the abyss. Through the work of A.Mamajonov, well acquainted with the life and image of his people, created graphic drawings with elegant and unique compositions. His works tell us about folk holidays and celebrations, as well as the local way of life. The artist A.Mamajonov, who regularly works on the stage with dreams, uses a realistic style in his work. Demonstration of the strong features of the local people, volume, and proportionality, restraint from the extravagant elements typical of naturalists, and a tendency to humor are characteristic of the artist's graphics. In this regard, he continued the tradition of the famous graphic artist and grateful artist TelmanMuhammedov. A.Mamajonov's experience in the field of painting will help him in this. He tries to imitate his compositions exactly as he did with his right hand, without reworking them with his left hand. In his work, the struggle and the market compositions of the old city can be singled out.

The role of the National Institute of Art and Design named after KamoliddinBehzod in the development of graphic arts and the preservation of graphic traditions is commendable. AsliddinKalanov, KhurshidZiyakhanov, NusratillaAbdullaev, NosirKhusanov, LayloBasharova, NarimonSharipov and JamshidRashidov continue their creative work by preserving the traditions of the School of Graphic Arts and imparting their knowledge and experience to young professionals.

AsliddinKalonov is one of the leading artists in the field of modern graphics. Many of the artist's colorful and philosophical works are created in a variety of genres and techniques. In particular, from watercolors, watercolors, gouache, tempera, simple pencils, dream-feathers, lithography, linocut and etching techniques. 
The cover of the novel "Fields left by my father", by the People's Writer of Uzbekistan TogayMurod, was based on school traditions formed in the last century. He then turned to this novel and drew several illustrations. These illustrations can convey the main reality of the novel to the viewer. In this way, he contributes to the development of young professionals as masters of their profession.

We can see that NarimanSharipov tried to preserve the traditions of the school in the workshop of the institute building, effectively using the lithographic method of graphics.

Based on her knowledge and experience, LayloBasharova now teaches students how to work with illustrations dedicated to various folk tales. Of course, K.Basharov's contribution to this is significant.
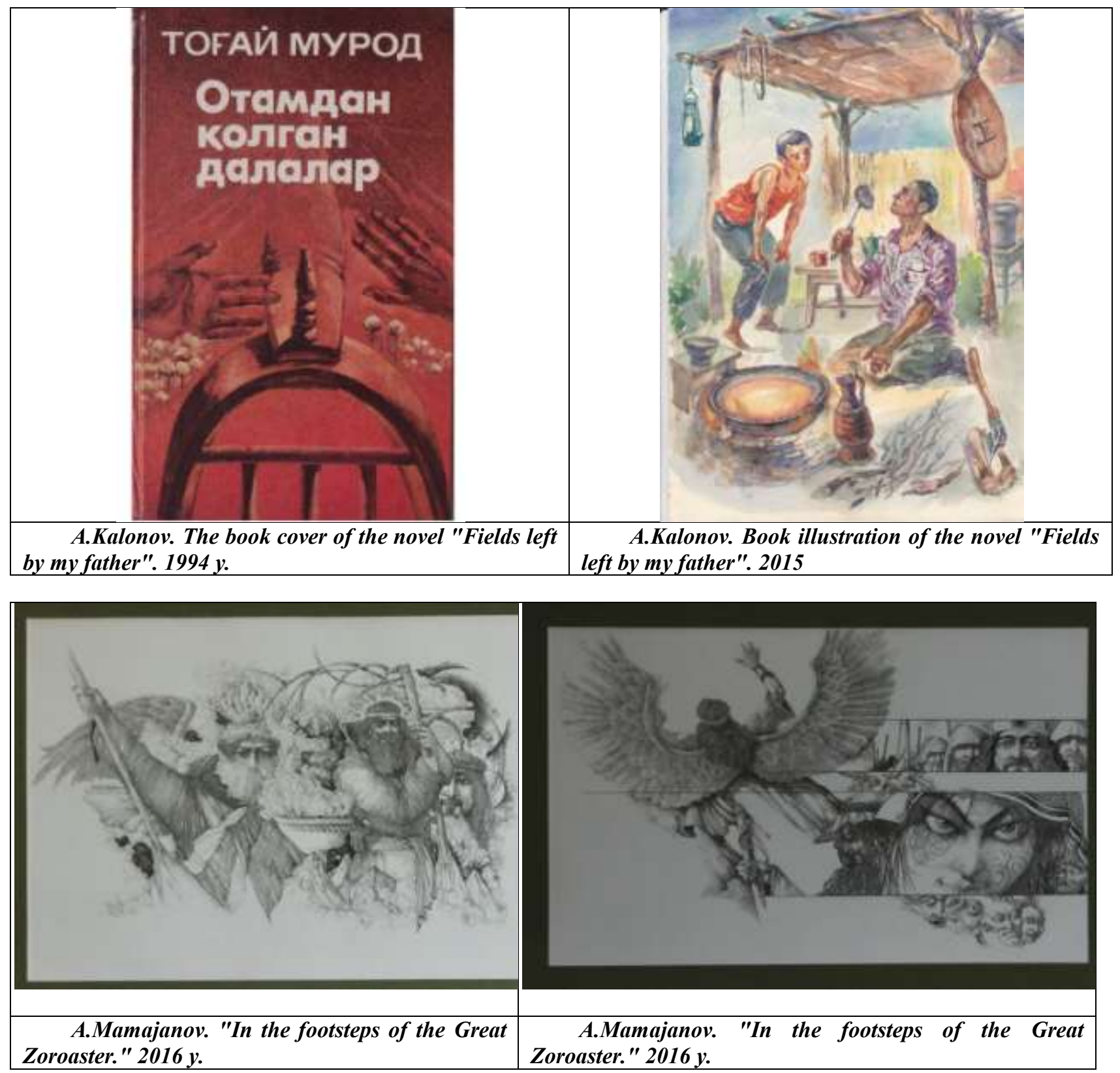

\section{Conclusion:-}

In conclusion, it is worth noting the following. Providing practical links between institutes and enterprises in the field of graphics would contribute to the further development of this art form. It is necessary to update the material 
and technical base and laboratory equipment, and bring it to a modern look. It is essential to develop a separate concept for the development of graphic arts and organize exhibitions on a regular basis. And it is also important to take steps to solve the existing problems in this area.

\section{References:-}

1. Rempel L.I. Art of Soviet Uzbekistan 1917-1972 - Moscow, 1976.

2. Taktash R.Kh. Modern graphics of Uzbekistan. - Tashkent, 1973.

3. Abdullaev N.U. History of art of Uzbekistan. - Toshkent, 2007.

4. Khakimov A.A. History of arts of Uzbekistan. - Tashkent, 2018.

5. Editorial board: Soviet graphics 79/80. - Moscow, 1981.

6. Ziganshina N.A. The art of books in Uzbekistan. - Tashkent, 1978.

7. Taktash R.Kh. Artistically critical sketches. - Tashkent, 1992.

8. Editorial board: Research book and materials. - Moscow, 1961.

9. "San`at" magazines.

10. www.arboblar.uz.

11. www. ziyonet. uz. 